\title{
Estimation of Settlement under Shallow Foundation for Different Regions in Iraq Using SAFE Software
}

\author{
Entidhar Al-Taie ${ }^{1,2}$, Nadhir Al-Ansari'2, Sven Knutsson' ${ }^{2}$ \\ ${ }^{1}$ Reconstruction and Projects Department, Minister of Higher Education and Scientific Research, Baghdad, Iraq \\ ${ }^{2}$ Department of Civil, Environment and Natural Resources Engineering, Lulea University of Technology, Lulea, \\ Sweden \\ Email: Entidhar.altaie@ltu.se, nadhir.alansari@ltu.se, Sven.Knutsson@ltu.se
}

Received 9 June 2015; accepted 11 July 2015; published 14 July 2015

Copyright (C) 2015 by authors and Scientific Research Publishing Inc.

This work is licensed under the Creative Commons Attribution International License (CC BY). http://creativecommons.org/licenses/by/4.0/

\section{(c) (i) Open Access}

\section{Abstract}

Foundation design must satisfy limited values of settlement. Settlement is an essential criterion in the design process of shallow foundations. To calculate the settlement under different types of shallow foundations, 79 samples were taken from twenty-three sites distributed in three regions: Mosul, Baghdad and Basrah in the northern, central and southern parts of Iraq. Field and laboratory tests were performed to obtain the strength parameters to calculate the bearing capacity. The results obtained for the bearing capacity were used in SAFE software. The software was used to design and analyze the foundation and to calculate the settlements under two types of foundations (raft and continuous) for the three regions. Average and minimum values of bearing capacity were used. The software used subgrade reaction modules values for the design and analysis. According to the results, the suitable, safe and economical type of foundation to be used in Mosul, Baghdad and Basrah regions for the average value of bearing capacity is the continuous type for the first two regions while the raft type is recommended for Basrah region. In case that the minimum bearing capacity values are used, raft foundation is recommended for Mosul and Baghdad. While deep foundation is the suitable type of foundation for Basrah region.

\section{Keywords}

Raft Foundation, Silt, Clay, Settlement, SAFE

\section{Introduction}

The design of foundations must satisfy limiting values of the settlement. Settlement is an essential criterion in 
the design process of shallow foundations. Settlement prediction is a major concern for designers. The two major criteria which control the design of shallow foundations on cohesion and cohesionless soils are the settlement and the bearing capacity of the soil beneath the foundation. Settlement usually controls the design process more than bearing capacity, especially when the width of foundation (B) exceeds 1 meter. Estimation of settlement of shallow foundations on soil facing problem related to uncertainty associated with the factors which affect the value of the settlement. These factors are: the history of the stress-strain of the soil, the distribution of applied stresses, the effect of soil compressibility, and the difficulty in obtaining undisturbed samples of cohesionless soil [1]. There are three types of settlements: uniform settlement, tilt and non-uniform settlement (Figure 1). Uniform settlement will not cause any damages in the structure but damages can be noticed in the drainage or at interface with utilities.

The most problematic settlement is the non-uniform type because it leads to structural distortions such as cracking of beams, slabs, etc. If the cracks appear in every floor of the structure it is due to foundation movement. Whilst, tilting is a problem with rigid and lean structures such as soils, tanks and towers [3].

Total excessive or differential settlements are sometimes related to unexpected consolidation. The stressstrain behaviour of soil is nonlinear from very small strains; it may have controlling influence on the scale and shape of the distribution of displacement of structure on soil. For that, design approach must be simple that can be related to collapse limits and successfully serviceable to the real nature of the soil [4]. Settlement is usually estimated depending on field test such as standard penetration test (SPT) and cone penetration test (CPT). Laboratory test is also used to obtain settlement values such as oedometer and triaxial tests. Another method for estimating settlement is computer modelling which depends on finite element analysis.

The aim of the research is to calculate the settlement of different sites in three locations, Mosul, Baghdad and Basrah in the northern, central and southern parts of Iraq respectively. SAFE software was used to calculate settlement under two types of foundations to choose the best type for each site.

\section{Study Area}

The study was conducted Mosul (9 sites), Baghdad (5 sites) and Basrah (9 sites) at the northern, central and southern parts of Iraq (Figure 2).

\subsection{Mosul Location}

Mosul is located at northern part of Iraq. The area is characterised by extensive plains and anticlines. Near the Tigris River there are three levels of accumulated terraces of alluvial soils. Most of the soil in the area is of moderate expansive type. Flat areas between the anticlines are covered by sheet run-off sediments which include clay, sand, silt, and sometimes coated by scattered gravels [5] [6].

\subsection{Baghdad Location}

Baghdad is located at the northern part of Mesopotamian plain. The area is characterized by sediments of flat laying alluvium due to flood of the two rivers (Tigris and Euphrates). Quaternary sediments soil (thickness more than $80 \mathrm{~m}$ ) covers the area, which include levee silts, clay and some sand. The main features of this area are the salinity and shallow ground water table between 1 to $5 \mathrm{~m}[7]$.

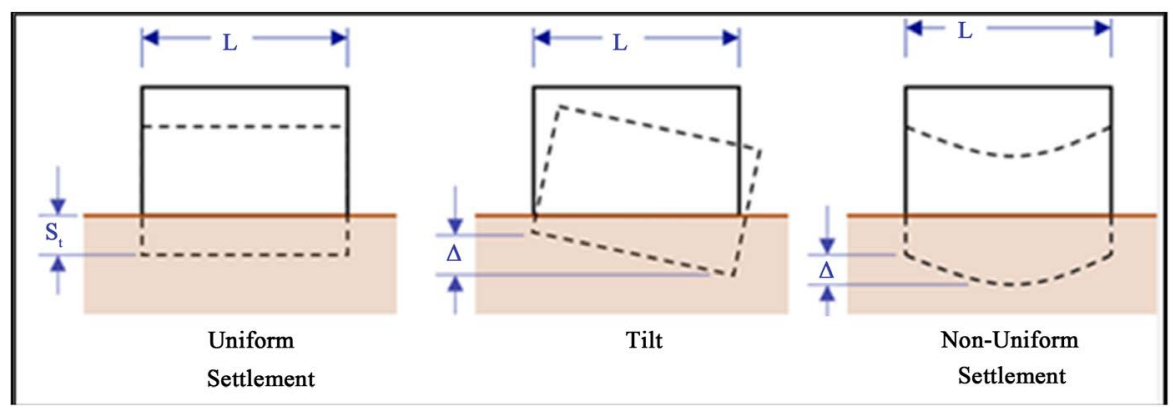

Figure 1. Types of settlement in soil [2]. 


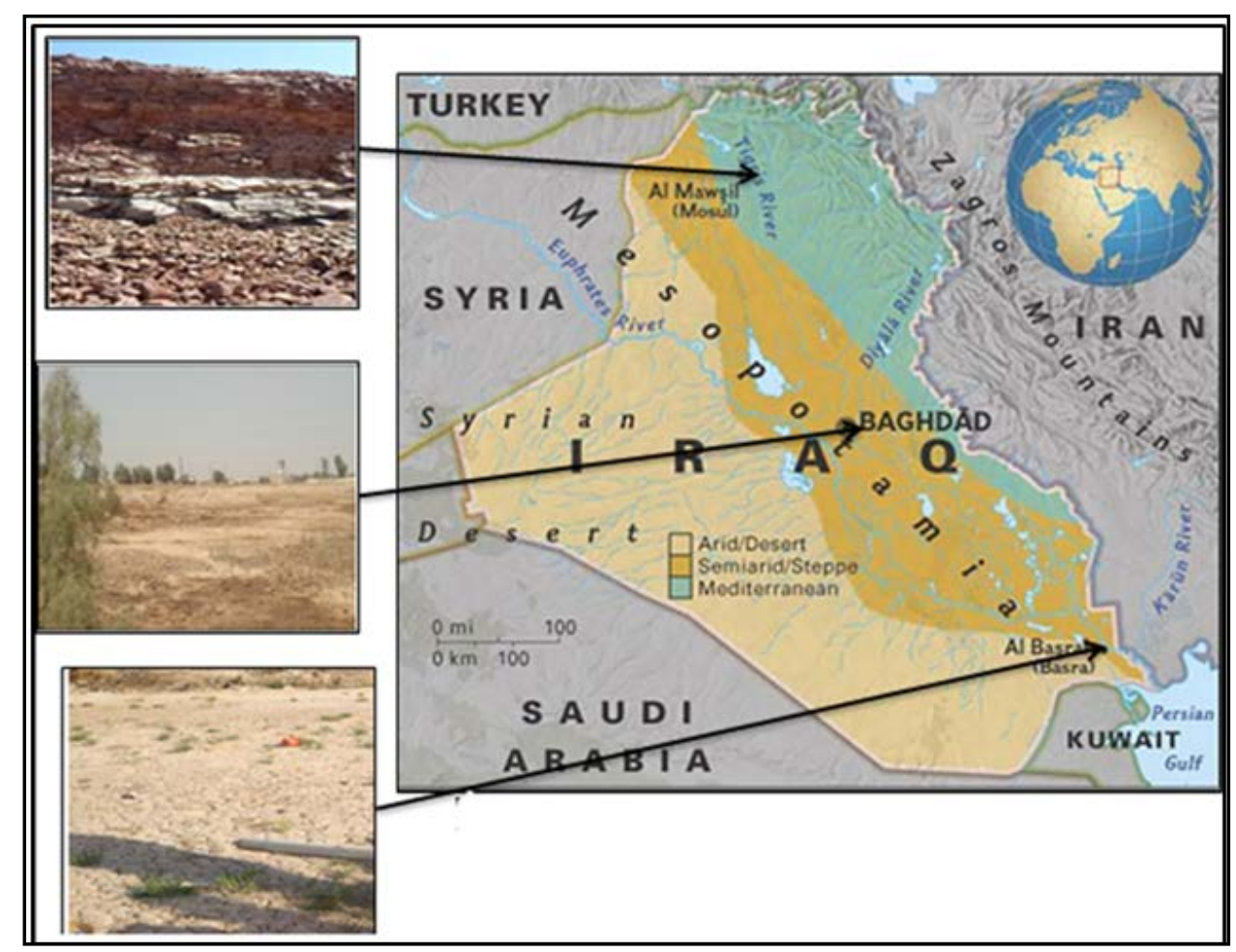

Figure 2. Locations of Mosul, Baghdad and Basrah map and soil type.

\subsection{Basrah Location}

Basrah is located at the southern part of Iraq. The soil of the area is about $250 \mathrm{~m}$ thick of flat thick quaternary sediment. The area represents the lower part of Mesopotamian plain. Its soil is of deltaic and river sediments type characterized by distinct change and exchange facies horizontally and vertically. The soil of the area is a combination of silt and mud river spate and wind sediments. These deposits are economically important as raw materials for the building and construction industries [8] [9].

\section{Experimental Work}

Soil investigations included field and laboratory tests. Field work includes drilling twenty three boreholes in different sites for the three locations (Mosul, Baghdad and Basrah) of Iraq. Seventy nine samples were collected (disturbed and undisturbed). Furthermore, standard penetration test (SPT) also performed in some of the sites. Laboratory tests conducted on the collected samples from sites included different types of tests. All the tests were done according to ASTM, AASHTO and BS as follow:

- Physical tests including, natural moisture content, unit weight and specific gravity.

- Sieve and hydrometer analysis.

- Atterberg limits (liquid limit LL and plastic limit PL to obtain plastic index PI).

- Shear tests (direct shear strength and unconfined compression).

- Consolidation test to obtain the compression index $\left(\mathrm{C}_{\mathrm{c}}\right)$, swelling index $\left(\mathrm{C}_{\mathrm{s}}\right)$ and preconsolidation pressures $\left(\mathrm{P}_{\mathrm{c}}\right)$.

The results obtained from shear tests to determine the shear strength were the angle of internal friction $(\phi)$, the cohesion (C) and unconfined compression $\left(\mathrm{q}_{\mathrm{u}}\right)$ [10]. These parameters were used to calculate bearing capacity value for each site using the general equation [11].

\section{SAFE Modelling}

Computation of settlement in this paper was done using SAFE software. SAFE software is a finite element tool used to design and analyze foundations, slab, mat and basement. It has powerful modelling tools with an intui- 
tive graphical interface. Design is integrated with modelling and the analysis is based on a chosen design code calculation. SAFE software can be used as a standalone programme or can import complete design, analysis and detailing of concrete floor plates created in SAP 2000 or ETABS. The SAFE software gives a variety of outputs that can be used to study the behavior of loads and deformations [12] [13].

The principle of the software is the ability to compute a plate displacements and resultant stresses with an acceptable degree of accuracy in order to ensure a safe and economical design. Modelling the soil is difficult method because soil has very complex nature. Winkler foundation model is the principle of the analysis of the foundation used in the software to obtain the results of displacement under foundation [14].

The geometry of model of study was raft foundation of $(25 * 60) \mathrm{m}$ used for different regions (Mosul, Baghdad, and Basrah) in Iraq. The used data in the software which were based on the calculated bearing capacities as shown in Table 1, and the soil subgrade reaction modulus (Ks). The combination loads (dead and live) were used according to ACI code [10]. The type of finite element used in the software was shell type where the mesh was generated automatically.

\section{Results and Discussions}

SAFE software was used to estimate settlement values. SAFE software analyzed the raft and continuous foundations depending on the subgrade reaction of the soil under the foundation for each site in the three regions. The results were illustrated in the form of contours as follows:

The displacement under foundation for the average value of bearing capacity in Mosul region is shown in Figure 3 for both raft and continuous types; the displacement value was $5.2 \mathrm{~mm}$ and $6 \mathrm{~mm}$ respectively. For the minimum value of bearing capacity, the displacement under raft and continuous foundation are show in Figure 4. The value of the displacement is $11 \mathrm{~mm}$ and $14 \mathrm{~mm}$ for raft and continuous types respectively.

Whilst, for Baghdad region, the displacement value distributed under raft and continuous foundations for the average value of bearing capacity was $8.4 \mathrm{~mm}$ and $8.8 \mathrm{~mm}$ respectively as shown in Figure 5. For the minimum bearing capacity value the displacement was $13.5 \mathrm{~mm}$ under raft type and $16 \mathrm{~mm}$ under continuous type (Figure 6).
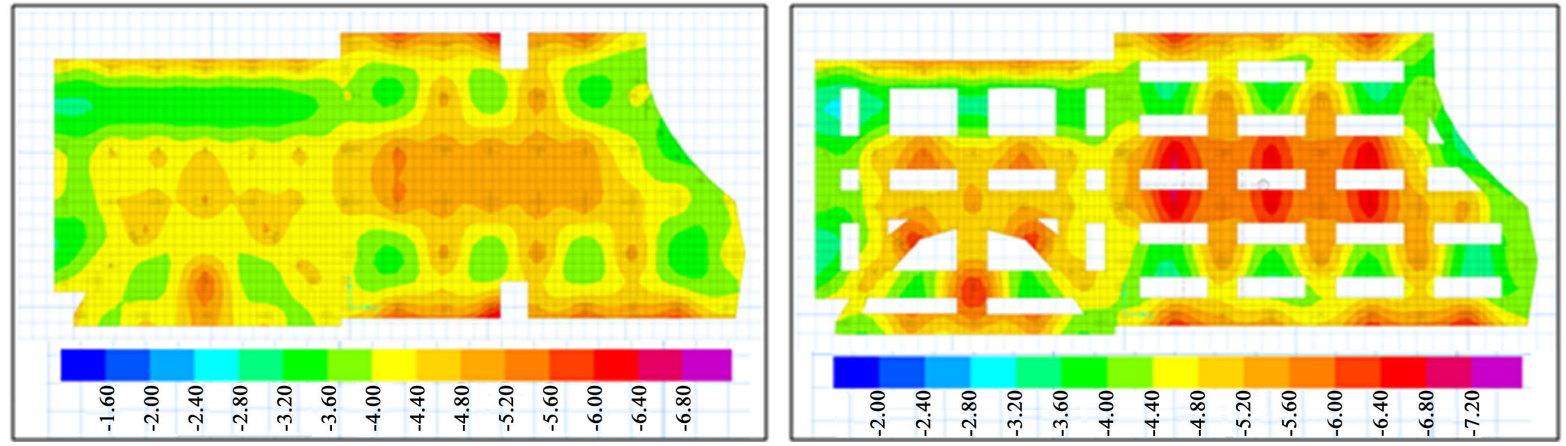

Figure 3. Displacement under raft and continuous foundation for average value of bearing capacity in Mosul region.
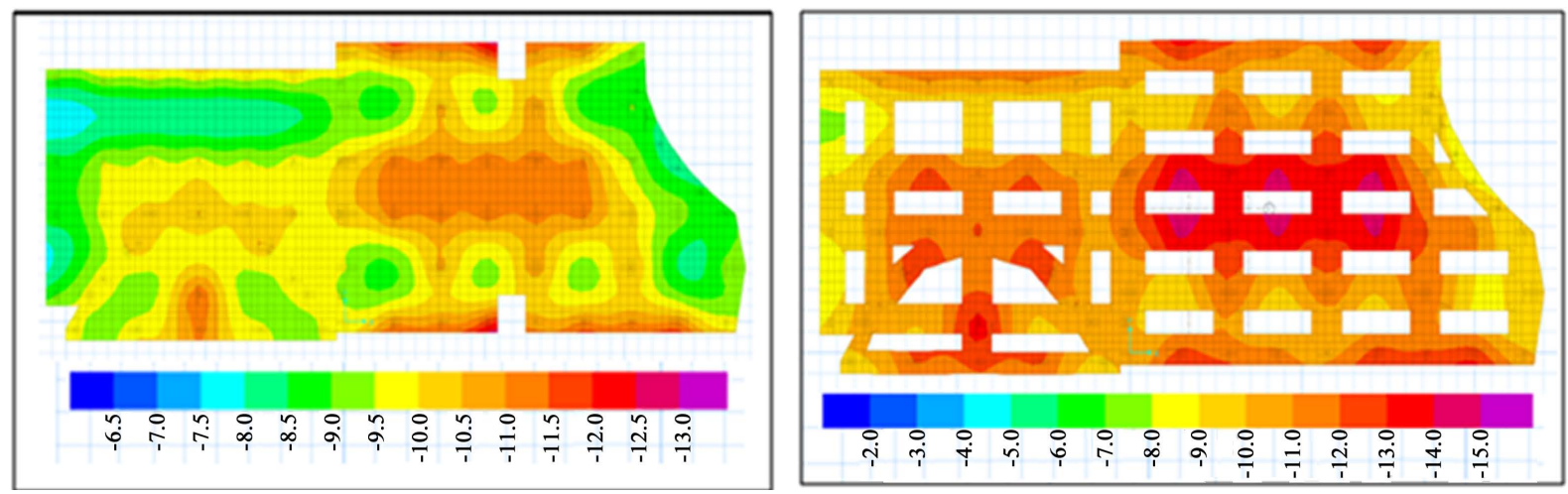

Figure 4. Displacement under raft and continuous foundation for minimum value of bearing capacity in Mosul region. 

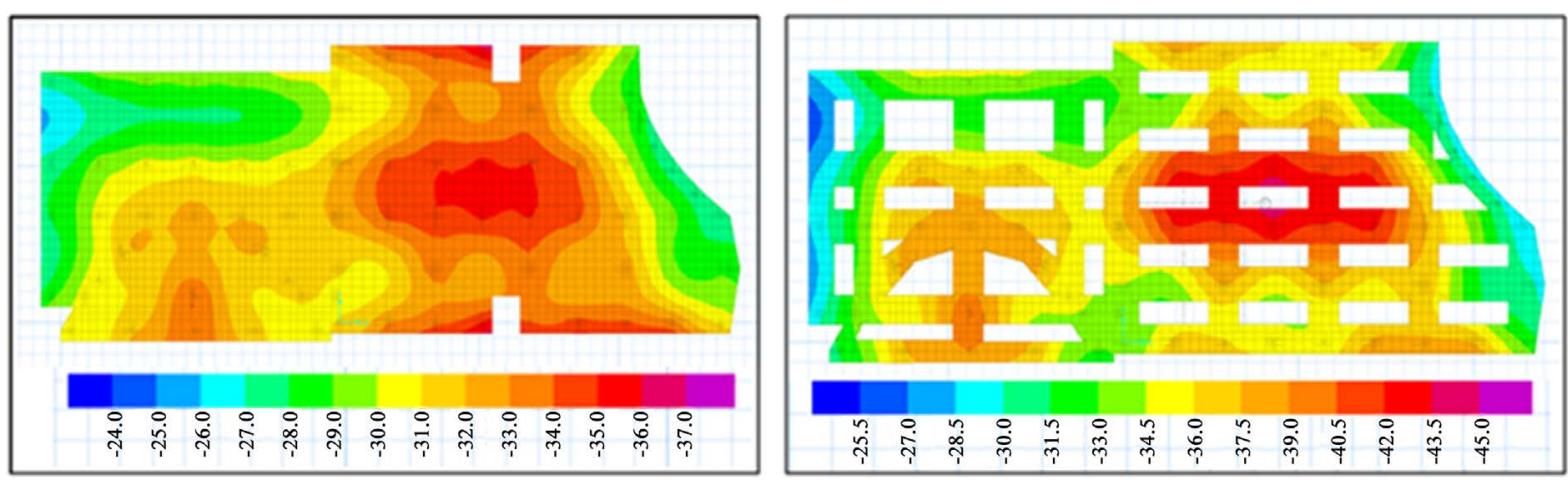

Figure 5. Displacement under raft and continuous foundation for average value of bearing capacity in Baghdad region.
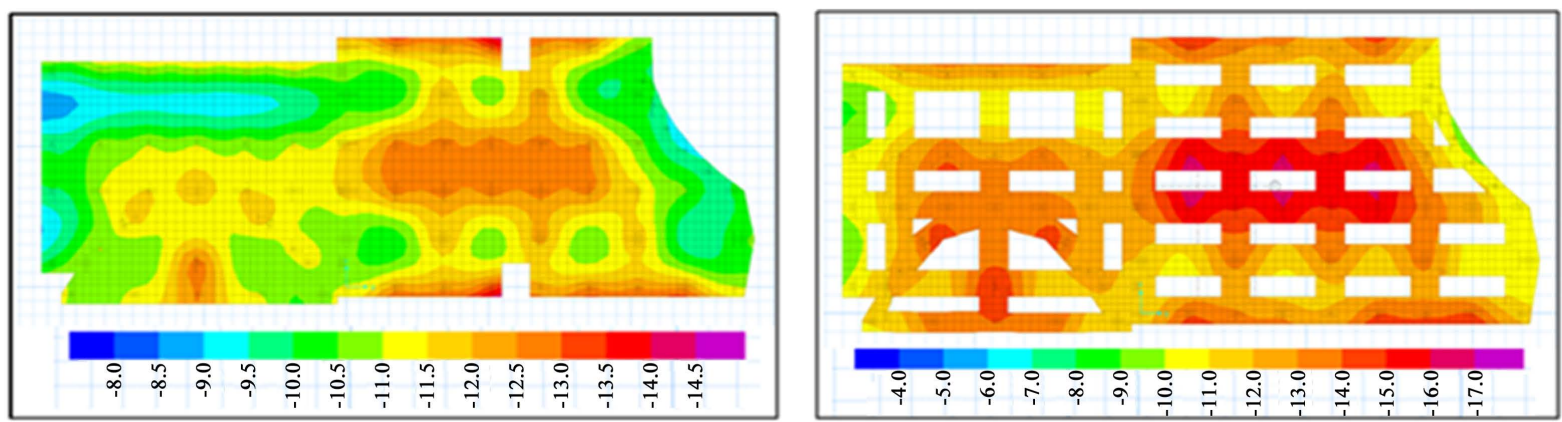

Figure 6. Displacement under raft and continuous foundation for minimum value of bearing capacity in Baghdad region.

Table 1. Bearing capacity for the three locations.

\begin{tabular}{cccc}
\hline Subgrade reaction modulus, ${\mathrm{kN} \backslash \mathrm{m}^{3}}^{3}$ & Mosul & Baghdad & Basrah \\
\hline Average value & 21,240 & 15,000 & 10,080 \\
Minimum value & 9240 & 8160 & 2880 \\
\hline
\end{tabular}

For Basra region, the analysis done for the average and minimum baring capacity values and for the raft and continuous type are shown in Figure 7 and Figure 8 respectively. The value of the displacement for the average value under raft type was $10.5 \mathrm{~mm}$ and under continuous type was $13 \mathrm{~mm}$. Whilst the displacement for minimum value under raft type was $36 \mathrm{~mm}$ and under continuous type was $42 \mathrm{~mm}$.

SAFE software showed that the results for the settlements of soil under the foundation depended only on the subgrade reaction modules for the soil. The settlement obtained from the software was distributed horizontally. The behaviour of all soil layers cannot be seen because the software show only the results of top soil layer which is in contact with the foundation.

The settlement values for Mosul region: The contour for settlement under raft and continuous in Figure 3 shows that the values of the settlement are nearly close to each other for both types of foundations (raft $=5.2$ $\mathrm{mm}$; continuous $=6 \mathrm{~mm}$ ). Both types of foundation can be used in such areas. According to the cost of implementation where the total volume of raft and continuous foundations were equal to $955 \mathrm{~m}^{3}$ and $248 \mathrm{~m}^{3}$ respectively. Then the continuous type is relatively more appropriate. The results for the minimum bearing value for both types of foundations indicated that the values of settlement were $13.5 \mathrm{~mm}$ and $15 \mathrm{~mm}$ respectively (Figure 4). The contours for raft type showed that most of the settlement values distributed under foundation are 10.5 $\mathrm{mm}$ (with minor exceptions where few areas had the value of $13 \mathrm{~mm}$ ). While, the contour under the continuous foundation showed that most of the area had a value of $15 \mathrm{~mm}$. For that, raft type for such area is relatively more suitable and safe. Figure 9 illustrate settlement values for both types of foundations.

The settlement values for Baghdad region: The contour of settlement (Figure 5) under raft and continuous foundations for average bearing capacity values in Baghdad region give almost similar values (8.8 mm). For such areas, continuous type is the best because it is safe and economical. Whilst, the results for settlement under 

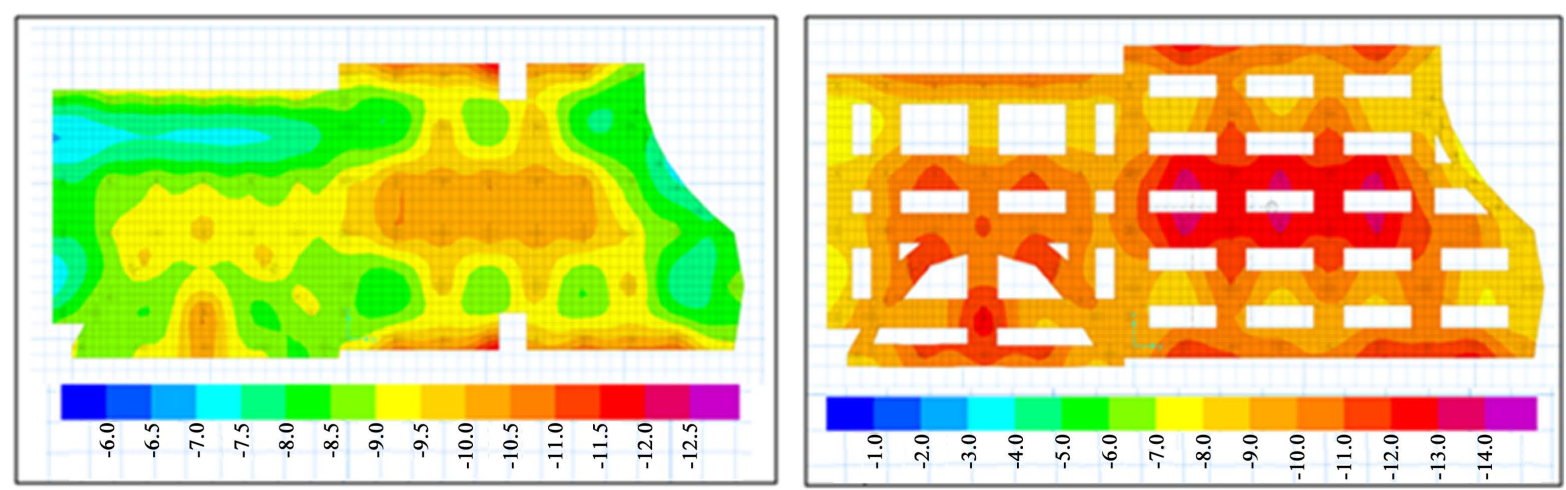

Figure 7. Displacement under raft and continuous foundation for average value of bearing capacity in Basrah region.
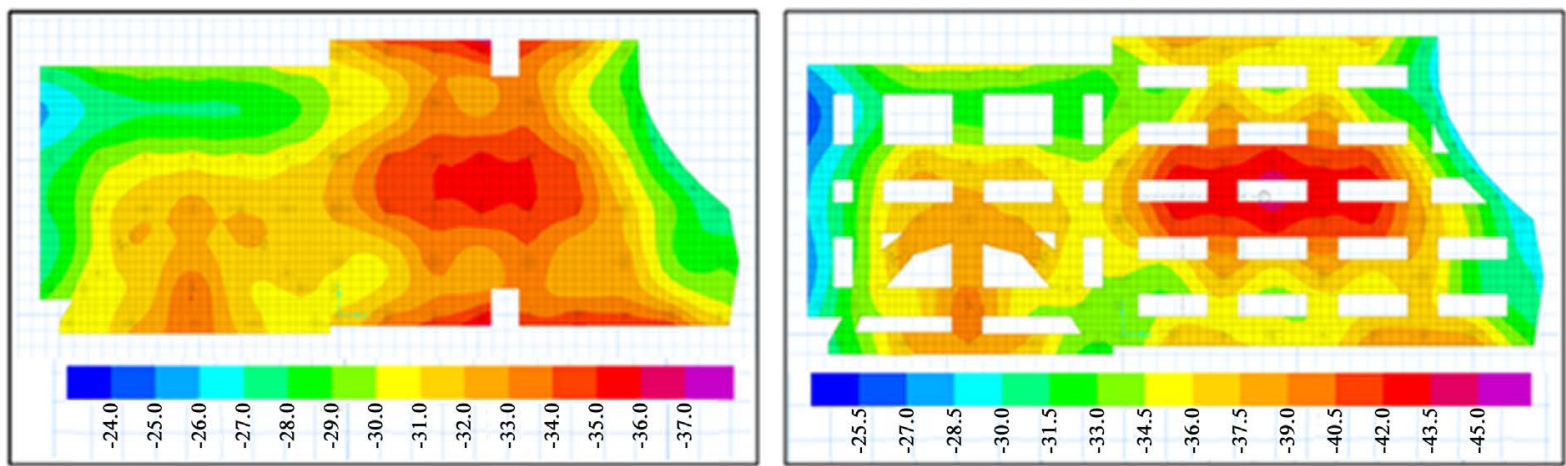

Figure 8. Displacement under raft and continuous foundation for minimum value of bearing capacity in Basrah region.

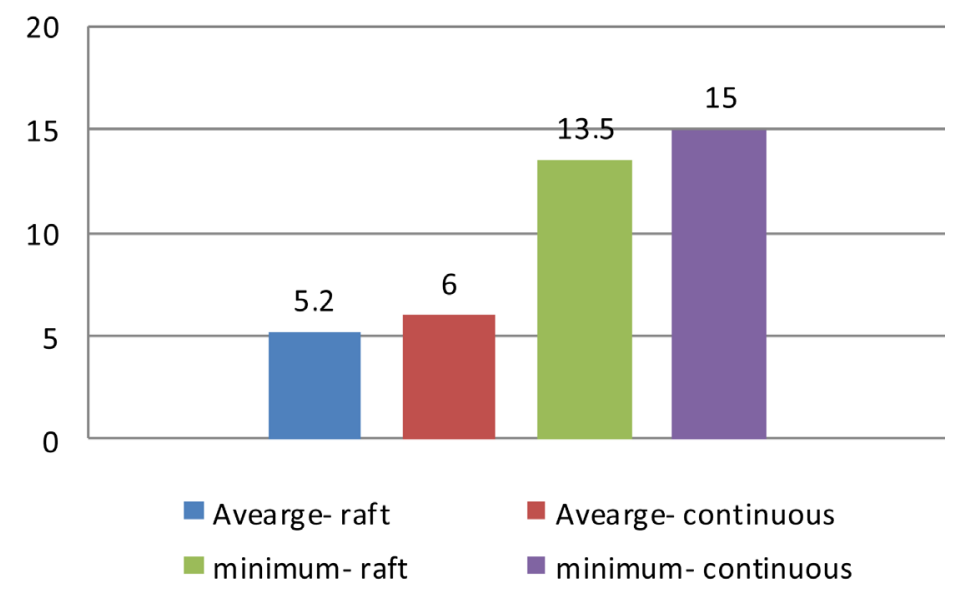

Figure 9. Settlement values under raft and continuous foundation for Mosul region.

raft and continuous foundations (Figure 6 and Figure 10) for minimum bearing capacity value showed that most of the area has values of $11.5 \mathrm{~mm}$ (few areas with $13 \mathrm{~mm}$ ) and16 mm respectively. For such area; the suitable type of foundation to be used is raft.

The settlement values for Basra region: The results in Figure 7 show that the settlement under raft foundation in most of the area is equal to $9.5 \mathrm{~mm}$ with few areas have $11.5 \mathrm{~mm}$ value. But the settlement value for most areas under continuous foundation is equal to $13 \mathrm{~mm}$. Therefore, for such areas, the suitable type is the raft. While the results of settlement under both types (raft and continuous) of foundation in Figure 8 and Figure 11 show that for the whole area has values of 36 and $42 \mathrm{~mm}$ respectively. The suitable type of foundation to be used is deep type. 


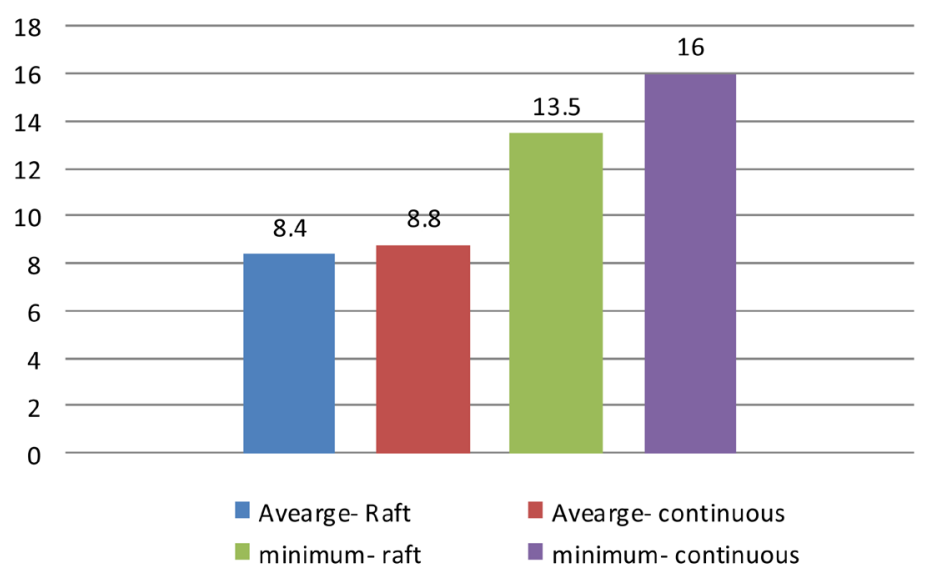

Figure 10. Settlement values under raft and continuous foundation for Baghdad region.

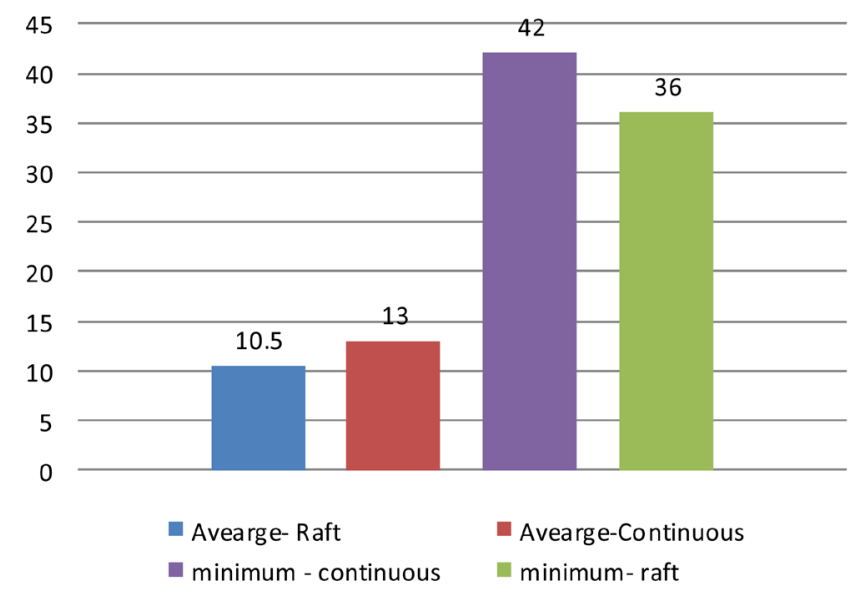

Figure 11. Settlement values under raft and continuous foundation for Basrah region.

\section{Conclusion}

SAFE software was applied on a hypothetical building on three regions in Iraq (Mosul, Baghdad and Basrah at the northern, central and southern parts of Iraq) to find out the most suitable foundation required in each region. According to the results, the suitable, safe and economical type of foundation to be used in Mosul, Baghdad and Basrah regions for the average value of bearing capacity is the continuous type for the first two regions while the raft type is recommended for Basrah region. In case that the minimum bearing capacity values are used, raft foundation is recommended for Mosul and Baghdad. While deep foundation is the suitable type of foundation for Basrah region. These results are satisfying the designer's requirements because the contour clarifies the displacements and cracking analysis.

\section{References}

[1] Shahin, M.A., Jaksa, M.B. and Maier, H.R. (2000) Predicting the Settlement of Shallow Foundations on Cohesionless Soils Using Back-Propagation Neural Networks. Research Report No. R 167, University of Adelaide, Adelaide.

[2] The CITADEL (2010) CIVL410 Geotechnical Engineering II-Shallow Foundations. http://cee.citadel.edu/civl410/CIVL410/Course_Materials_files/CIVL410\%20Shallow\%20Foundation\%20-\%20Settle ment.pdf

[3] Salgado, R. (2013) Settlement and Serviceability, Piling Engineering. https://engineering.purdue.edu/COFFEE/courses/CE597PilingEngineering/2013Fall/lectures/Piling\%20Engineering\%2 0-\%20Lecture\%2003.pdf 
[4] Osman, A.S. and Bolton, M.D. (2004) A New Approach to the Estimation of Undrained Settlement of Shallow Foundations on Soft Clay. Engineering Practice and Performance of Soft Deposits, IS-OSAKA, 93-98.

[5] Buringh, P. (1960) Soils and Soil Condition in Iraq. Ministry of Agriculture, Baghdad.

[6] Jassim, S.Z. and Goff, J.C. (2006) Geology of Iraq. Dolin, Prague and Moravian Museum, Brno.

[7] Al-Taie, E., Al-Ansari, N., Knutsson, S. and Saaed, T.E. (2013) Foundation Assessment in Different Parts of Iraq Using STAAD Pro V8i. Journal of Civil Engineering and Architecture, 7, 273-281.

[8] Mahmood, R.A., Al-Marsomy, A.H. and Mohammad Ali, A.A. (2011) Study of Gypsum Content of Soils at Selected Sites in Basrah Governorate South of Iraq for Engineering Purposes. Journal of Basrah Researches (Sciences), 37, $10-21$.

[9] Muttashar, W.R. (2010) Some Geotechnical Soil Properties of Western Bank of Khor Al-Zubair Channel Coast at Khor Al-Zubair Port Location, Southern Basrah, Iraq. Mesopotamian Journal and Marian Science, 25, 124-133.

[10] Al-Taie, E., Al-Ansari, N., Saaed, T.E. and Knutsson, S. (2014) Bearing Capacity Affecting the Design of Shallow Foundation in Various Regions of Iraq Using SAP200 \& SAFE Softwares. Journal of Earth Sciences and Geotechnical Engineering, 4, 35-52.

[11] Das, M.B. (2010) Principle of Geotechnical Engineering. 7th Edition, Cengage Learning, Stamford.

[12] Key Features and Terminology (2009) SAFE Design of Slabs, Beams and Foundations Reinforced and Post-Tensioned concrete. Computers \& Structures, Inc., Berkeley.

[13] Computers and Structures, Inc. (2013) CSI Analysis Reference Manual. Berkley, California. https://docs.csiamerica.com

[14] Rajpurohit, V.K., Gore, N.G. and Sayagavi, V.G. (2014) Analysis of Structure Supported on Elastic Foundation. International Journal of Engineering and Advanced Technology (IJEAT), 4, 1-6. 